
\title{
A INFLUÊNCIA DO PÉ DIREITO E TÉCNICAS ARQUITETÔNICAS NO CONFORTO TÉRMICO NAS EDIFICAÇÕES.
}

Adriana P. R. Martins ${ }^{1}$; Phelippe M. de Paiva' ; Diogo H. Muniz ${ }^{3}$; Daniela S. Kodama ${ }^{4}$; Mariana Ferreira

Martins Garcia ${ }^{5}$; André Luiz Alves da Silva ${ }^{6}$

1,2, 3,4,5,6 Universidade de Uberaba (UNIUBE)

adrianaprm92@hotmail.com; andre.silva@uniube.br

\section{1 - Introdução}

Hoje a ANEEL enfrenta sérios problemas para conseguir suprir a demanda de energia de norte a sul do país, chegando quase a colapso nos horários de pico.

Sabendo que o consumo de energia do Brasil se configura da seguinte forma: consumo industrial 44\%, residência $25 \%$, comercial $16 \%$ e outros $15 \%$ (PROCEL, 2003), percebe-se a necessidade da tomada de ações para fazer com que os setores industrial e residencial reduzam seus gastos por serem os consecutivos maiores consumidores.

Grande parte dos gastos desses setores estão anexados ao uso de climatizadores artificiais para promover a convecção interna e consequentemente o conforto, sabendo que, para Fisbhen (2009) "A convecção se constitui de movimentos de massas fluidas, trocando de posição". Então esse conforto poderia ser alcançado com uso de métodos naturais e construtivos para proporcionar essas trocas de massas sem o uso de equipamentos, o que já pouparia uma parcela considerável de energia nesses setores.

Seguindo os desajustes apontados (elevado consumo energético e falta de conforto térmico na maioria das residências brasileiras), esse trabalho tem como primeira estância a realização de um estudo quantitativo e qualitativo da viabilidade das construções de pés direito mais altos (maior que o padrão de 2,80 m), para constatar os resultados da eficiência energética alcançada.

Assim, tendo como objetivo geral de avaliar o conforto térmico em ambiente residencial em função da altura do pé direito e técnicas de conforto térmico em regiões com clima quente.

\section{2 - Materiais e métodos}

$\mathrm{Na}$ primeira etapa do trabalho será realizado um estudo teórico entre os códigos de obras entre as cinco regiões do Brasil, com intuito de comparar as táticas e normas construtivas estabelecidas em relação ao pé direito e comparar os pradões entre as residências.

A segunda etapa será realizado um estudo comparativo de tecnicas arquitetônicas entre as residências de menor porte com o estilo antigo na cidade de Uberba-MG com 0 objetivo de mostrar as técnicas que eram utilizada há algumas décadas atrás, que permitiam 0 perfeito funcionamento das residências sem necessidade de climatização artificial. Também pretende-se realizar esse estudo entre as residências comuns e de alto padrão da cidade de Uberaba, analisando altura do pé direito e outras técnicas de conforto térmico.

Outra etapa do projeto será comparar o conforto térmico em uma sala padrão com $2,80 \mathrm{~m}$ e outra com $4,00 \mathrm{~m}$ de pé direito, avaliando o custo médio anual do ar condicionado, que será feito o dimensionamento da carga térmica por atribuição de fatores para, ganho por condução, insolação, ganho devido pessoas, dissipação elétrica, ventilação e infiltração, o valor encontrado multiplicado pelo consumo médio diário, também pode ser encontrado em tabelas disponibilizadas pela PROCEL, assim podendo determinando o custo médio anual. $O$ acréscimo de alvenaria para obter uma sala padrão de $4,00 \mathrm{~m}$ de pé direito será determinado pelo TCPO. E a verificação de temperatura dentro desses ambientes será feita utilizando termômetro de mercúrio fixado a 1,50 m em uma das paredes que não tenha aberturas próximas, estabilizar o equipamento e aferir temperatura interna dos ambientes durante 7 dias e obter temperatura média. 
8을 EnTec - Encontro de Tecnologia da UNIUBE / 28 a 30 de outubro de 2014

\section{3 - Resultados e discussão}

Com os experimentos a serem realizados em salas padrões com diferentes alturas de pé direitos e com estudos das técnicas arquitetônicas construtivas, espera-se provar a real necessidade de mesclar os parâmetros construtivos com o micro clima da região em análise, no caso Uberaba.

Mostrando que a elevação do pé direito aliada com aberturas previamente planejadas promove um aumento percentual na velocidade do vento, uma diminuição significativa da temperatura interna, aumento do indicie do conforto interno, e redução do uso de aparelhos de climatização artificial. $\mathrm{Na}$ figura abaixo é apresentado um Nomograma que relaciona os itens analisados (temperatura, velocidade do ar e umidade) em relação ao conforto térmico.

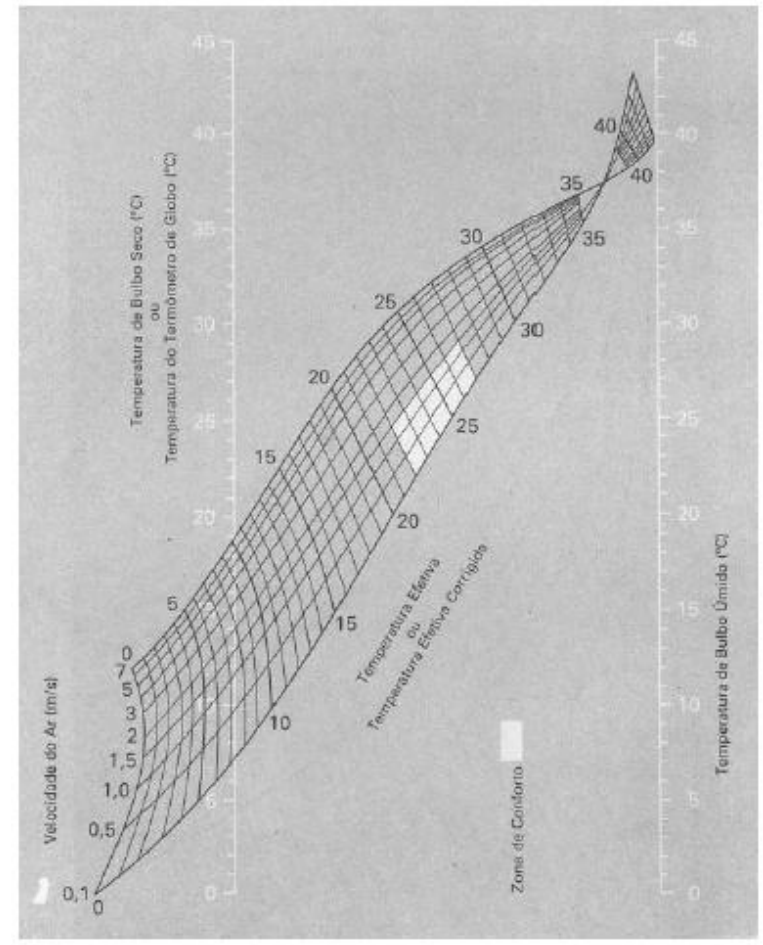

Figura 1 - Nomograma de temperatura efetiva para pessoas normalmente vestidas, em trabalho leve.

Assim provando a real necessidade de técnicas construtivas como a elevação do pé direito, que por si só mostrar-se-á um ganho percentual na velocidade do ar e queda da temperatura interna, quando acompanhado de aberturas, além da promoção da economia energética ao longo da vida útil da edificação.

\section{4 - Considerações finais}

O trabalho tem como meta central mostrar a viabilidade de se gastar um pouco mais durante a fase de projeto e execução das edificações com propostas sustentáveis de climatização natural, como: elevação do pé direito, sistema de aberturas cruzadas e utilização de brises. Para obtenção de residências que vão precisar de um pequeno funcionamento, ou nenhum, de equipamentos como o ar condicionado.

Isso porque através de experimentos e estudos comprovar-se-á a eficiências das técnicas construtivas para a obtenção do conforto interno e ainda será mostrado o período de "Payback" dos gastos iniciais com as técnicas construtivas em paralelo com o gasto de energia ao longo da vida útil da edificação com os equipamentos de climatização artificiais que deixaram de ser usados. Assim concluindo a viabilidade da construção de residências que atendem as necessidades dos microclimas aos quais estão inseridas.

\section{5 - Referências}

FISBHEN, Marcos. Transmissão de Calor, 2009. Disponível em: <http://www.desconversa.com.br/fisica/tag/co nveccao/>. Acesso em: abr. 2014.

MINISTÉRIO DE MINAS E ENERGIA. Balanço Energético Nacional 2013. Brasília: Ministério de Minas e Energia. 2013. 284 p.

PROGRAMA NACIONAL DE CONSERVAÇÃO DE ENERGIA ELÉTRICA. Eletrobrás/Procel premia municípios que se destacaram em eficiência energética. Informativo Eletrobrás do Programa Nacional e Conservação de Energia Elétrica. Rio de Janeiro, v. 67. p. 1-4. 2003.

\section{Agradecimentos}

À Universidade de Uberaba, pela disponibilização do laboratório de conforto térmico. Aos professores André Luiz da Silva e Mariana Ferreira Martins, por estarem acompanhando as atividades práticas, além de fornecerem explicações e exemplos necessários para boa condução do trabalho. 